\title{
Curcumin Analog CH-5 Suppresses the Proliferation, Migration, and Invasion of the Human Gastric Cancer Cell Line HGC-27
}

\author{
Gabriel Silva ${ }^{1, \dagger}{ }^{\dagger}$ Felipe Teixeira Lima ${ }^{1,+}{ }^{+}$, Viviane Seba ${ }^{1,+}{ }^{\text {, Ana Laura Mendes Lourenço }}{ }^{1,2}$, \\ Thaise Graminha Lucas 1,2, Bianca Vieira de Andrade 1,2, Guilherme Silva Torrezan ${ }^{3}$, \\ Carlos Roberto Polaquini ${ }^{3}$ (D), Marcelo Engracia Garcia ${ }^{2}$, Lucélio Bernardes Couto ${ }^{2}$, \\ Reinaldo Bulgarelli Bestetti ${ }^{2}$, Suzelei de Castro França ${ }^{1}$, Ana Lúcia Fachin 1,2, \\ Luis Octavio Regasini ${ }^{3, *}$ and Mozart Marins ${ }^{1,2, *}$ (D)
}

1 Biotechnology Unit, University of Ribeirão Preto, Av. Costábile Romano, 2201, Ribeirão Preto, SP CEP 14096-900, Brazil; biel-189@hotmail.com (G.S.); lima.ft@hotmail.com (F.T.L.); vivianeseba@gmail.com (V.S.); analaura.mendes@hotmail.com (A.L.M.L.); thaisegl.uru@hotmail.com (T.G.L.); bandrade@hotmail.com (B.V.d.A.); sfranca@unaerp.br (S.d.C.F.); afachin@unaerp.br (A.L.F.)

2 Medicine School, University of Ribeirão Preto, Av. Costábile Romano, 2201, Ribeirão Preto, SP CEP 14096-900, Brazil; mgarcia@unaerp.br (M.E.G.); lubercouto@gmail.com (L.B.C.); rbestetti@unaerp.br (R.B.B.)

3 Laboratory of Green and Medicinal Chemistry, Department of Chemistry and Environmental Sciences, Institute of Biosciences, Humanities and Exact Sciences, São Paulo State University (UNESP), São José do Rio Preto, SP CEP 15054-000, Brazil; guilherme_panz@hotmail.com (G.S.T.); carlos_polaquini@hotmail.com (C.R.P.)

* Correspondence: luisregasini@gmail.com (L.O.R.); mmarins@gmb.bio.br (M.M.)

$\dagger$ These authors contributed equally to this work.

Received: 22 December 2017; Accepted: 18 January 2018; Published: 30 January 2018

\begin{abstract}
Gastric cancer is one of the most frequent malignant tumors in the world. The majority of patients are diagnosed with metastatic gastric cancer, which has a low survival rate. These data reinforce the importance of studying the anticancer activity of new molecules with the potential to suppress gastric cancer metastasis. Curcumin is a well-studied compound that has demonstrated anti-metastatic effects. Here we investigated if $\mathrm{CH}-5$, a curcumin derivative compound, has anti-metastatic properties in the human gastric cancer cell line HGC-27. Firstly, we found that CH-5 decreased viability and induced apoptosis in HGC-27 cells in a dose-dependent manner. Additionally, CH-5 suppressed the migration and invasion of HGC-27 cells by downregulating the expression and collagenase activity of matrix metalloproteinase 2 in a dose-dependent manner. In conclusion, CH-5 showed anticancer activities, including the induction of apoptosis, and the suppression of migration and invasion in HGC-27 cells, suggesting that $\mathrm{CH}-5$ can be a lead molecule for the development of anti-metastatic drugs for gastric cancer therapy.
\end{abstract}

Keywords: gastric cancer; curcumin; matrix metalloproteinase 2; migration; invasion; apoptosis

\section{Introduction}

Gastric cancer (GC) is one of the most commonly diagnosed types of malignant tumors worldwide and it is the third leading cause of cancer-related deaths. In humans, GC can be connected to life habits, viral infection, and genetic or environmental factors [1]. The survival of people with GC is still low, with only about $24 \%$ exhibiting a five-year survival rate. This high mortality is due to late diagnosis, often when the cancer has already metastasized [2]. Based on this, studies related to the genetics of GC, new therapeutic targets, and drugs are needed to change this scenario. 
The degradation of the extracellular matrix (ECM) is an important mechanism for the maintenance and renewal of tissues in general. On the other hand, the deregulation of this process plays a role in the development of some types of cancer, such as gastric cancer [3]. There are several proteins involved in the degradation of the ECM; however, the matrix metalloproteinases (MMPs) are considered the most important [4].

Metalloproteinases are zinc-dependent endopeptidases that can degrade all components of the ECM [4]. Based on structure and function, MMPs can be divided into: collagenases 1, 2, 3 (MMP-1, -8 and -13, respectively), stromelysins 1 and 2 (MMP-3 and -10), gelatinases (MMP-2 and -9), and membrane-type MMPs (MT-MMP), respectively MMP-14, -15, -16, -17, -24, and -25 [4,5]. Matrix metallopeptidase 2 (MMP-2), which is classified as type IV collagenase, is one of the most important metalloproteinases because it can degrade different types of collagens. In addition, MMP-2 is the most expressed MMPs and it is found in the vast majority of tissues and cells [6,7]. MMP-2 plays a crucial role in the migration and invasion of cancer cells. Through the degradation of basement membrane proteins (specialized ECM), this MMP can facilitate stromal and vascular invasion by tumor cells, thus allowing these cells to spread to distant sites from the primary tumor [8,9]. Some studies report the high expression of MMP-2 in several types of cancer, among them the GC, and for that reason the inhibition of this metalloproteinase becomes a potential attempt to control tumor progression and metastasis [10,11].

Natural small molecules could be significant therapeutic agents for the treatment of numerous diseases, including cancer. Among these molecules, curcumin, a phenolic compound obtained from the rhizomes of Curcuma longa L., has been widely studied and has shown antioxidant, anti-inflammatory, and anticancer activity [12]. Furthermore, curcumin has been demonstrated to inhibit cancer progression by suppressing MMP-2 activity [13-15]. However, curcumin shows poor solubility that results in low bioavailability. A variety of experimental studies based on cells and animals have shown that structural modifications in the $\beta$-diketone moiety, the aromatic rings, or the flanking double bonds conjugated to the $\beta$-diketone moiety of curcumin can improve its bioavailability, besides enhancing the anticancer activity [16]. Our research group has been screening monoketone analogs of curcumin and selected CH-5 (4,4'-[(2-Oxo-1,3-cyclohexanediylidene)-di(E)methylylidene]dibenzonitrile) as an interesting compound to be tested for anticancer activity in different tumor cells [17,18]. In the present study, we demonstrated that $\mathrm{CH}-5$ suppresses cell migration and invasion accompanied by the inhibition of MMP-2 in the human gastric cell line HGC-27.

\section{Results}

\subsection{CH-5 Reduces Cell Viability and Induces Apoptosis in a Gastric Cancer Cell Line}

To determine the effects of $\mathrm{CH}-5$ (Figure 1A) on gastric cancer cell viability, we treated HGC-27 cells with $\mathrm{CH}-5$ at different doses for $24 \mathrm{~h}$. The MTT results showed that $\mathrm{CH}-5$ reduced the viability of HGC-27 cells in a dose-dependent manner with significant inhibition (51\%) at $20 \mu \mathrm{M}$ (Figure 1B). To verify whether the reduction of HCG-27 cell viability was correlated to the induction of apoptosis, we performed Annexin V-FITC/PI double staining using flow cytometry. In conformity with the inhibition of cell viability, the $\mathrm{CH}-5$ also increased apoptosis in a dose-dependent manner; the fold induction of apoptosis was 2.0, 3.9, and 4.3 in HGC-27 cells treated with CH-5 at 10, 20, and $40 \mu \mathrm{M}$, respectively (Figure 1C). Caspase 3 activity is also a biomarker of apoptosis and, as shown in Figure 1D, the treatment of HGC-27 cells with increasing concentrations of CH-5 resulted in augmented levels of caspase 3 activity. The data indicated that $\mathrm{CH}-5$ has an antiproliferative effect on gastric cancer cells mediated by apoptosis induction. 
$\mathbf{A}$

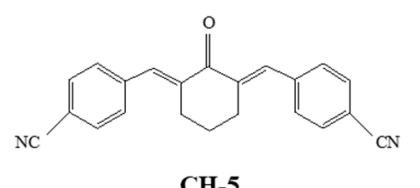

CH-5

C

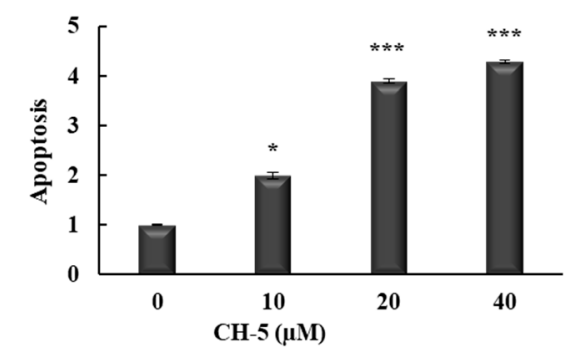

B

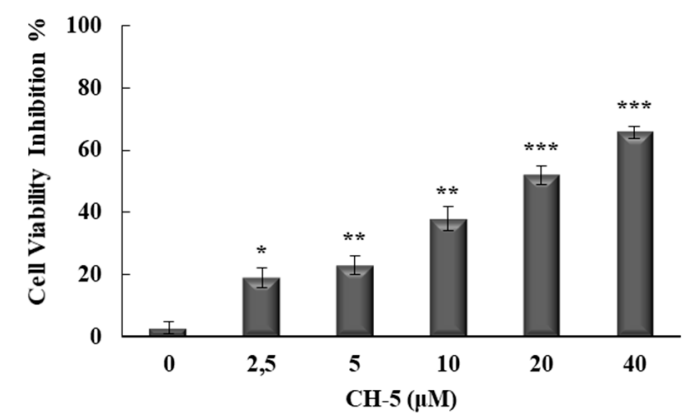

D

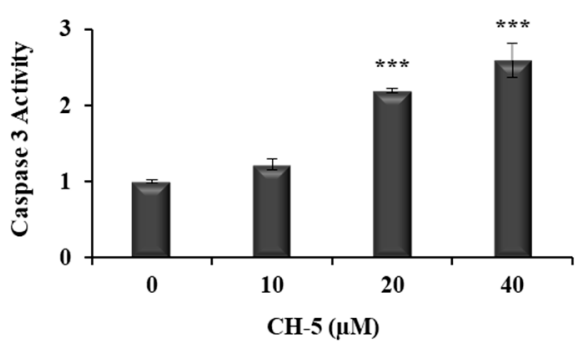

Figure 1. Cellular viability of HGC-27 cells treated with $\mathrm{CH}-5$. (A) Chemical structure of $\mathrm{CH}-5$; (B) HGC-27 cells were treated with DMSO (0.1\%) or with $0,2.5,5,10,20,40 \mu \mathrm{M}$ of CH-5, and after $24 \mathrm{~h}$ their viability was measured by an MTT assay. Each experiment was performed in quadruplicate; (C) Apoptosis induction by CH-5. HGC-27 cells were treated with DMSO (0.1\%), or 10, 20, and $50 \mu \mathrm{M}$ of $\mathrm{CH}-5$, and after $24 \mathrm{~h}$ the rate of apoptotic cells was assessed by double staining (Annexin V-FITC/PI) flow cytometry assay. Y-axis represents fold induction compared to DMSO-treated cells; (D) Apoptosis was further confirmed by measuring caspase 3 activity in HGC-27 cells treated with $\mathrm{CH}-5$. After treatment with $\mathrm{CH}-5$ at the indicated concentrations, protein lysates were mixed with caspase- 3 substrate, and then caspase- 3 activity was determined by measuring absorbance, according to the manufacturer's instructions described in the materials and methods section. Y-axis represents relative caspase activity compared to DMSO-treated cells. In all experiments, the data represent the mean \pm SD of three experiments. ${ }^{*} p \leq 0.05,{ }^{* *} p \leq 0.01$, and ${ }^{* * *} p \leq 0.001$ compared with DMSO control.

\section{2. $\mathrm{CH}-5$ Decreases Migration and Invasion in a Gastric Cancer Cell Line}

We evaluated the effect of $\mathrm{CH}-5$ on HCG-27 cell migration and invasion using a wound-healing assay and a Transwell assay. The wound-healing assay showed that $\mathrm{CH}-5$ significantly inhibited wound closure in a concentration-dependent manner (Figure 2A). In order to confirm the cell migration inhibition mediated by $\mathrm{CH}-5$, we performed a Transwell assay. In agreement with the wound-healing assay, as shown in Figure 2B, the treatment with $\mathrm{CH}-5$ for $24 \mathrm{~h}$ dramatically reduced the number of HGC-27 cells that had migrated through the Transwell membrane in a dose-dependent manner, with substantial inhibition (79.8\%) at $20 \mu \mathrm{M}$. To evaluate the effect of $\mathrm{CH}-5$ on cell invasive capacity, we used Transwell coated with Matrigel, as shown in Figure 2C; a number of HGC-27 cells that had invaded the Matrigel was significantly decreased (92\%) by $\mathrm{CH}-5$ at $20 \mu \mathrm{M}$. 
A
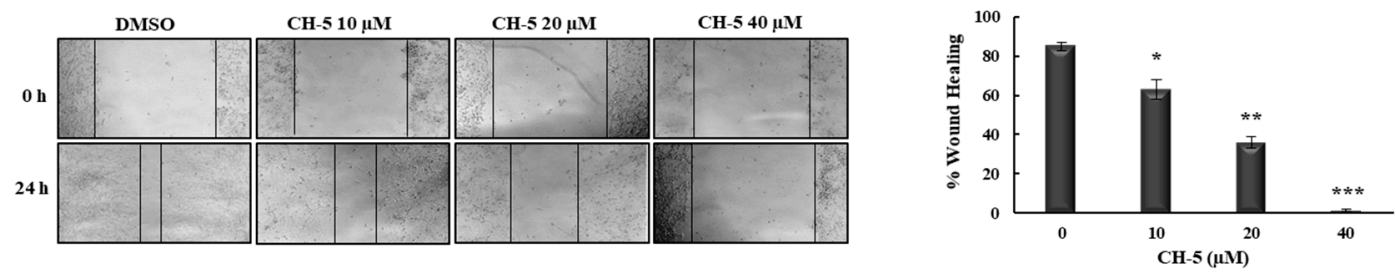

B
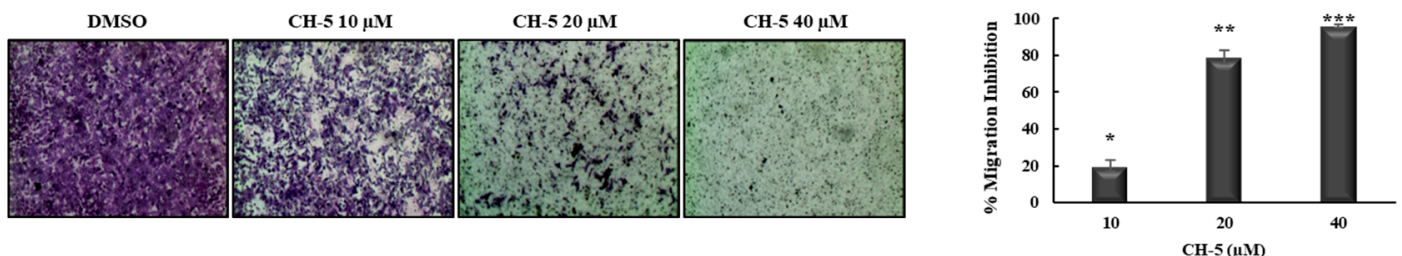

C
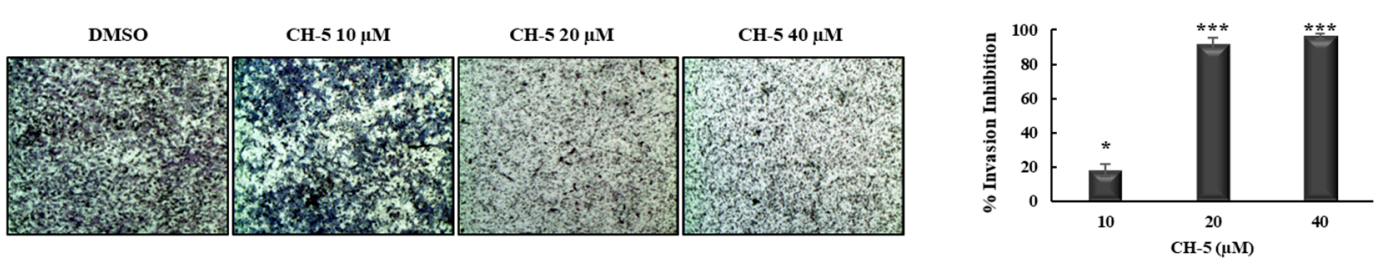

Figure 2. CH-5 inhibited cell migration and invasion in HGC-27 cells. (A) The effect of $\mathrm{CH}-5$ on HGC-27 cell migration was evaluated by a wound healing assay. HGC-27 cells were scratched and treated with $0,10,20$, and $40 \mu \mathrm{M}$ of $\mathrm{CH}-5$ for 0 and $24 \mathrm{~h}$. The migration was observed under a phase-contrast microscope at a magnification of $40 \times$. Migration inhibition (\%) after treatment with $\mathrm{CH}-5$ was calculated, and quantitative results are illustrated in the right panel; (B) The inhibitory effect of $\mathrm{CH}-5$ on HGC-27 cell migration was detected by a Transwell assay. Cells in serum-free medium were plated onto the upper chamber of the Transwell. Complete medium ( $10 \%$ serum) containing $\mathrm{CH}-5$ at the indicated doses was added to the lower chamber. After $24 \mathrm{~h}$, cells on the bottom side of the Transwell membrane were stained and observed by manual counting and measuring absorbance at $490 \mathrm{~nm}$. Migration Inhibition (\%) was calculated and quantitative results are illustrated in the right panel; (C) For the invasion assay, the Transwell membrane was pre-coated with Matrigel, following which the cells were plated and treated as described above. Invasion Inhibition (\%) was calculated and quantitative results are illustrated in the right panel. In all experiments, the data represent the mean \pm SD of three experiments. ${ }^{*} p \leq 0.05,{ }^{* *} p \leq 0.01$, and ${ }^{* * *} p \leq 0.001$ vs. DMSO group.

\subsection{CH-5 Reduces the Transcriptional Levels and Activity of MMP-2}

HGC-27 cells were treated for $24 \mathrm{~h}$ with $0,10,20$, and $40 \mu \mathrm{M}$ of $\mathrm{CH}-5$, and then the transcripts of MMP-2 were measured by conventional RT-PCR. We found that mRNA levels of MMP-2 were decreased by $\mathrm{CH}-5$ in a dose-dependent manner with a significant reduction (fold-5.5) at $20 \mu \mathrm{M}$ (Figure 3A). To evaluate whether MMP-2 downregulation at the transcription level by CH-5 affects its activity, we performed a Gelatin zymography assay. HGC-27 cells were treated for $24 \mathrm{~h}$ with indicated doses of $\mathrm{CH}-5$, and then the activity of MMP-2 was assessed. $\mathrm{CH}-5$ treatment reduced the MMP-2 collagenase activity in a dose-dependent manner with a remarkable effect at $20 \mu \mathrm{M}$ (fold-2.3) (Figure 3B). 
A

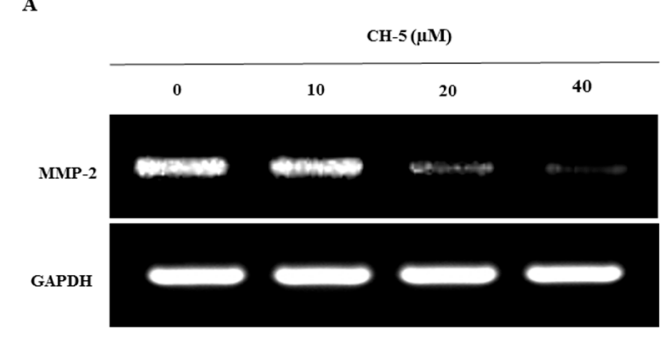

B

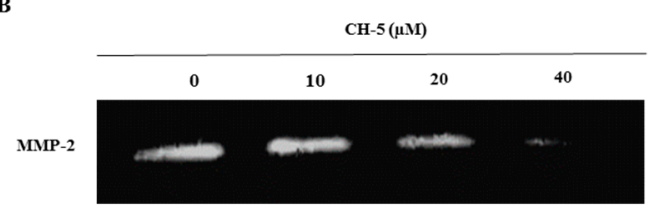

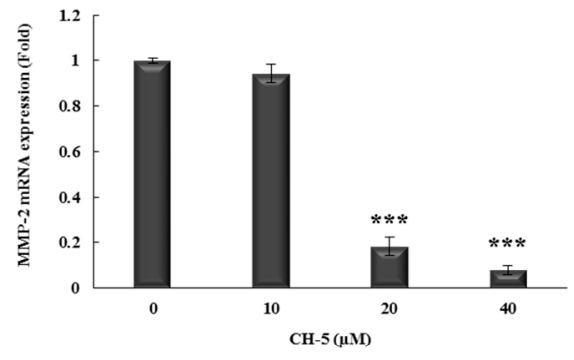

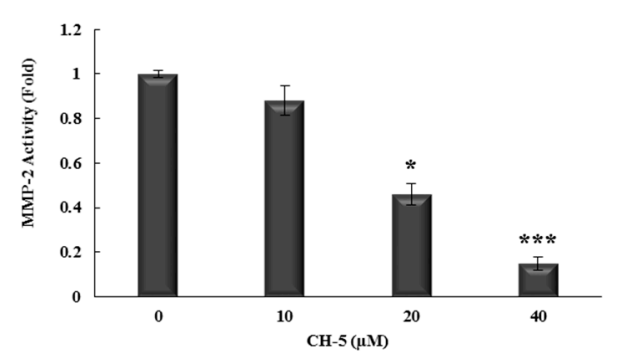

Figure 3. $\mathrm{CH}-5$ decreased transcriptional levels and protease activity of MMP-2 in HGC-27 cells. (A) HGC-27 cells were treated with 0,10 , or $40 \mu \mathrm{M}$ of $\mathrm{CH}-5$; after $24 \mathrm{~h}$ the total RNA was isolated and then subjected to conventional RT-PCR using primers for MMP-2 and housekeeping gene GAPDH. A representative gel (left) and densitometry analysis from three independent experiments (right) are shown; (B) HGC-27 cells were treated with $\mathrm{CH}-5(0,10,20$, and $40 \mu \mathrm{M})$ for $24 \mathrm{~h}$ and then the activity of secreted MMP-2 was measured by gelatin zymography assay. A demonstrative gel (left) and quantitative results (right) from three independent experiments are presented. In all experiments, ${ }^{*} p \leq 0.05$ and ${ }^{* * *} p \leq 0.001$ vs. DMSO-treated cells.

\section{Discussion}

Metastasis is a complex process involving various steps: detachment, invasion, intravasion, migration to distant sites through the circulatory system, extravasation, and proliferation of cancer cells in competent organs. Initially, metastatic cells need to detach from the primary tumor, migrate and invade the basement membrane, then enter and travel into the blood and lymph vessels, leave the vascular system, and lastly adhere and grow at a distant site $[19,20]$. Metalloproteinases, through the degradation of the extracellular matrix, play a crucial role in all these steps; consequently, a common strategy of tumor cells to trigger metastasis is the overexpression of metalloproteinases, mostly MMP-2 [17,18].

Based on this, target MMP-2 expression in cancer cells is a reasonable strategy for decreasing metastasis, and the use of dietary compounds, in particular curcumin, has gained attention [13-15,21,22]. We have studied the anticancer effects of $\mathrm{CH}-5$, a curcumin derivative, which has been shown in our studies to have better potential anticancer activities than curcumin.

In the present study, we investigated whether $\mathrm{CH}-5$ has antiproliferative and pro-apoptotic properties and, finally, whether $\mathrm{CH}-5$ inhibits migration and invasion in gastric cancer cells by reducing the expression of MMP-2.

In order to clarify the cytotoxic effect of CH-5 on a gastric cancer cell line (HGC-27), an MTT assay was performed. We found that $\mathrm{CH}-5$ significantly suppressed cell viability in a dose-dependent manner in HGC-27 cells. To elucidate whether the suppression of HGC-27 cell viability was associated with the induction of apoptosis, we used flow cytometry analysis. In agreement with the reduction of cell viability, treatment with $\mathrm{CH}-5$ increased apoptosis in a dose-dependent manner. We have found in other cell lines that $\mathrm{CH}-5$ is capable of inducing $3 / 7$ caspase activity and then promoting the cleavage of PARP $[17,18]$, and curcumin has already been shown to induce caspases-mediated apoptosis in gastric cancer [23,24]. Thus, $\mathrm{CH}-5$ is likely to trigger apoptosis in gastric cancer cells by the induction of caspases. 
We further used wound-healing and Transwell assays to investigate the effect of $\mathrm{CH}-5$ on cell migration and invasion. As it has been demonstrated in vitro and in vivo, curcumin suppresses the migration and invasion of cancer cells $[15,25]$. Here, we observed that $\mathrm{CH}-5$ also suppresses migration and invasion in gastric cancer cell line HGC-27 in a dose-dependent manner. Interestingly, at the same dose, $\mathrm{CH}-5$ inhibited migration and invasion more strongly than cell viability (Figures $1 \mathrm{~B}$ and 2B), suggesting that the anti-metastatic effect of $\mathrm{CH}-5$ is not only linked to cytotoxicity.

MMP-2 is a critical protease for tumor cell migration and invasion by degrading the extracellular matrix. Overexpression of MMP-2 has been associated with increased tumor metastasis and worse prognosis in several cancers, including gastric cancer [10,11]. Building on this knowledge, we evaluated whether the inhibition of migration and invasion mediated by $\mathrm{CH}-5$ was associated with the alteration of MMP-2 activity. First, through conventional RT-PCR analysis, we found that $\mathrm{CH}-5$ can downregulate MMP-2 gene expression. Next, using a zymography assay, we observed that CH-5 also decreased MMP-2 collagenase activity. It has been shown that the inhibition of MMP-2 expression appears to be connected to the reduction of transcription factor Sp1 [26,27], and we have found in other cancer cell lines that $\mathrm{CH}-5$ decreases the levels of Sp1 protein $[17,18]$; so probably the anti-migration and anti-invasion effects of $\mathrm{CH}-5$, at least in part, can be related to the downregulation of the Sp1/MMP-2 axis.

In this study, we found that $\mathrm{CH}-5$, a curcumin-related compound, reduces cell viability by the induction of apoptosis in gastric cancer cell line. Furthermore, $\mathrm{CH}-5$ decreases the expression and activity of MMP-2 protein, which plays a critical role in cancer cell migration and invasion. The data presented points toward further studies on the potential anti-metastatic activity of $\mathrm{CH}-5$.

\section{Materials and Methods}

\subsection{Cell Culture and Chemicals}

The human gastric cancer cell line HGC-27 was purchased from the Rio de Janeiro Cell Bank (BCRJ, Federal University of Rio de Janeiro, Rio de Janeiro, Brazil). HGC-27 cells were grown in Dulbecco's Modified Eagle Medium (Sigma-Aldrich ${ }^{\circledR}$, St. Louis, MO, USA) supplemented with $10 \%$ fetal bovine serum (FBS), $100 \mathrm{U} / \mathrm{mL}$ penicillin, and $100 \mu \mathrm{g} / \mathrm{mL}$ streptomycin (Sigma-Aldrich ${ }^{\circledR}$ ). Cells were cultured at $37{ }^{\circ} \mathrm{C}$ under a humidified atmosphere of $5 \% \mathrm{CO}_{2}$ for all experiments. $\mathrm{CH}-5$, a curcumin analog (Figure 1A), was provided by Dr. Luis Octávio Regasini (Department of Chemistry and Environmental Chemistry, São Paulo State University, São Paulo, Brazil).

\subsection{Cell Viability Assay}

The cell viability of HGC-27 cell was measured by an MTT assay. In brief, cells were seeded in 96-well plates at a density of $5 \times 10^{3}$ cells/well. After an overnight culture, cells were treated in quadruplicate with $0,2.5,5,10,20$, or $40 \mu \mathrm{M}$ of $\mathrm{CH}-5$ for $24 \mathrm{~h}$. DMSO was used as a solvent at a final concentration of $0.1 \%$, which is considered atoxic for the cells. After treatment, the medium was replaced with fresh medium; $20 \mu \mathrm{L}$ MTT solution $(5 \mathrm{mg} / \mathrm{mL})$ was added to each well, and the plates were incubated for an additional $3 \mathrm{~h}$. The absorbance was then measured spectrophotometrically at a wavelength of $550 \mathrm{~nm}$ by a microplate reader (MultiSkan FC, Thermo Scientific, Waltham, MA, USA). The results were plotted as the percentage of inhibition of cell viability (ICV) calculated as follows: $\operatorname{ICV}(\%)=[1-($ absorbance of treated group/absorbance of control group $)] \times 100$. Data represent the average \pm SD from three independent experiments combined.

\subsection{Apoptosis Assay}

Apoptosis analysis was performed with double labeling (Annexin- $\mathrm{V} /$ propidium iodide), using an FITC Annexin V Apoptosis Detection Kit I (BD Biosciences), according to the manufacturer's recommendations, with slight modifications. HGC-27 cells were grown in a $60-\mathrm{mm}$ dish to $80 \%$ confluence, then treated with 10,20 , or $40 \mu \mathrm{M}$ of $\mathrm{CH}-5$ in a medium with $10 \%$ FBS for $24 \mathrm{~h}$. 
After this treatment, adherent and floating cells were collected by centrifugation, washed with PBS, and resuspended in $300 \mu \mathrm{L}$ of $1 \times$ binding buffer. Next, $5 \mu \mathrm{L}$ of FITC Annexin V and $5 \mu \mathrm{L}$ of propidium iodide were added and the cells were incubated at room temperature in the dark for 15 min. Finally, cells were analyzed using a BD FACSCalibur ${ }^{\mathrm{TM}}$ Flow Cytometer (BD Biosciences, San Jose, CA, USA).

\subsection{Caspase 3 Assay}

The activity of caspase 3 was assessed using a caspase 3 colorimetric assay (Sigma-Aldrich ${ }^{\circledR}$ ). The HGC-27 cells cultured in 60-mm plates were treated with 10, 20, or $40 \mu \mathrm{M}$ of CH-5 in a medium with $10 \%$ FBS for $24 \mathrm{~h}$. Next, protein lysates were obtained in $1 \times$ lysis buffer. Then, $30 \mu \mathrm{g}$ of total proteins (in $10 \mu \mathrm{L}$ ) were distributed into 96-well plates and mixed with $80 \mu \mathrm{L}$ of $1 \times$ assay buffer and $10 \mu \mathrm{L}$ of caspase- 3 substrate. After incubation at $37^{\circ} \mathrm{C}$ in the dark for $3 \mathrm{~h}$, the absorbance was measured at $405 \mathrm{~nm}$ by a microplate reader (MultiSkan FC).

\subsection{Wound-Healing Assay}

A wound-healing assay was performed to analyze cell migration capacity according to the published protocols of literature with minor modifications [28]. Briefly, HCG-27 cells were grown in 24-wells plate until the cell monolayer reached nearly $100 \%$ confluency, then a wound was created with a sterile $10-\mu \mathrm{L}$ pipette tip. Floating cells were removed, and attached cells were exposed to the indicated concentration of $\mathrm{CH}-5$ for 0 and $24 \mathrm{~h}$. After the incubation time, the scratched areas were photographed in an optical microscope. The wound area was measured using ImageJ software (ImageJ2, National Institutes of Health, Bethesda, MD, USA). Migration rates of CH-5 group and DMSO group were calculated as follows: Migration rate $(\%)=[($ wound area at $0 \mathrm{~h}-$ wound area at $24 \mathrm{~h}$ )/wound area at $0 \mathrm{~h}] \times 100 \%$.

\subsection{Transwell Assay}

A Transwell cell assay was used to analyze the effect of $\mathrm{CH}-5$ on the migration and invasion capacity of HCG-27 cells, according to the published protocols of literature with minor modifications [29]. Briefly, cells were serum-starved overnight, and then $2 \times 10^{5}$ cells resuspended in $200 \mu \mathrm{L}$ serum-free medium were seeded into the upper chamber of a 24-well Transwell plate with an $8 \mu \mathrm{m}$ pore size (Corning, Corning, NY, USA). Into the lower chamber, $750 \mu \mathrm{L}$ of complete medium (with 10\% serum) containing different concentrations of CH-5 was added. After treatment for $24 \mathrm{~h}$, the migrated cells attached on the bottom side of the Transwell membrane were fixed with $3.7 \%$ of paraformaldehyde for 2 min, permeabilized with methanol 100\%, and stained with Wright's Giemsa solution for $15 \mathrm{~min}$ at room temperature. For the invasion assay, the membrane of the Transwell was pre-coated with $0.75 \mathrm{~mm}$ of Matrigel (Corning ${ }^{\circledR}$ ) according to the manufacturer's instructions, and then the same step detailed for the migration assay was performed. Either for migration and invasion, the cells were destained with $100 \mu \mathrm{L}$ of cells of $33 \%$ acetic acid. The destaining solution was collected and the absorbance was measured at a wavelength of $490 \mathrm{~nm}$ by a microplate reader (MultiSkan FC). The inhibition of migration or invasion was calculated as follows: Inhibition $(\%)=[1-$ (absorbance of treated group/absorbance of control group)] $\times 100$. Data represent the average \pm SD from three independent experiments.

\subsection{Reverse Transcription-Polymerase Chain Reaction (RT-PCR)}

Conventional RT-PCR was performed to analyze the matrix metalloproteinase-2 (MMP-2) expression. In short, HCG-27 cells were seeded in 6-well plates at a density of $5 \times 10^{5}$ cells/well and cultured overnight. Next, the cells were treated with $0,10,20$, or $40 \mu \mathrm{L}$ of $\mathrm{CH}-5$ in serum-free medium for $24 \mathrm{~h}$. After treatment, total RNA was isolated using Illustra ${ }^{\mathrm{TM}}$ RNASpin Mini Kit (GE Healthcare, Little Chalfont, UK) and treated with DNase I Amplification Grade (Sigma-Aldrich ${ }^{\circledR}$ ). Then, $1 \mu \mathrm{g}$ of RNA was used for the synthesis of cDNA using a High-Capacity cDNA Reverse Transcription kit (Applied Biosystems). PCR was carried out using RedTaq Mix (Sigma-Aldrich ${ }^{\circledR}$ ) with human primers 
as follows: MMP-2 Fwd $5^{\prime}$-ttcccettcttgttcaatgg- $3^{\prime}$ and Rev $5^{\prime}$-atttgttgcccaggaaagtg- $3^{\prime}$; and GAPDH Fwd $5^{\prime}$-gaccacagtccatgccatcact- $3^{\prime}$ and Rev $5^{\prime}$-tccaccaccetgttgctgtag- $3^{\prime}$. The thermal cycling conditions were as follows: initial denaturation at $94{ }^{\circ} \mathrm{C}$ for $2 \mathrm{~min}$, followed by 26 cycles of $94{ }^{\circ} \mathrm{C}$ for $30 \mathrm{~s}, 60^{\circ} \mathrm{C}$ for $30 \mathrm{~s}$ and $72{ }^{\circ} \mathrm{C}$ for $30 \mathrm{~s}$, and a final extension at $72{ }^{\circ} \mathrm{C}$ for $5 \mathrm{~min}$. The PCR products were electrophoresed on $1.5 \%$ agarose gel and photographed under UV light. The intensity of bands was analyzed by densitometry using the GAPDH band (constitutive expressing gene) as a reference.

\subsection{Gelatin Zymography}

Gelatin zymography was performed to quantify the matrix metalloproteinase-2 (MMP-2) activity. Briefly, HCG-27 cells were cultured in 6-well plates $\left(5 \times 10^{5}\right.$ cells/well) followed by treatment with $0,10,20$, or $40 \mu \mathrm{L}$ of $\mathrm{CH}-5$ in serum-free medium for $24 \mathrm{~h}$. After treatment, the supernatant (conditioned medium) for each sample was collected and then separated by $0.1 \%$ gelatin- $7 \%$ SDS-PAGE electrophoresis. Next, the gels were washed in 2.5\% Triton X-100 three times ( $30 \mathrm{~min}$ each) at room temperature and incubated in reaction buffer $\left(10 \mathrm{mM} \mathrm{CaCl}_{2}, 40 \mathrm{mM}\right.$ Tris- $\mathrm{HCl}$, and $\left.0.01 \% \mathrm{NaN}_{3}, \mathrm{pH} 8.0\right)$ at $37^{\circ} \mathrm{C}$ for $18 \mathrm{~h}$. Gels were washed with distilled water, and stained with Coomassie brilliant blue R-250. After destaining steps, bands were digitally scanned, and the gelatinolytic activities were measured using ImageJ software.

Acknowledgments: The authors gratefully acknowledge financial support from the Coordination for the Improvement of Higher Education Personnel (CAPES), the National Research Council (CNPq) (Grants 471129/2013-5 and 306251/2016-7), Ministry of Education (Programa de Educação Tutorial), and the São Paulo Research Foundation (FAPESP) (Grants 2014/18330-0; 2014/15307-7; 2017/03237-2).

Author Contributions: G.S., F.T.L., A.L.F., M.M. conceived and designed the experiments; G.S., F.T.L., V.S., A.L.M.L., T.G.L., B.V.d.A., G.S.T., C.R.P. performed the experiments; G.S., F.T.L., A.L.F., L.O.R., M.M. analyzed the data; M.E.G., L.B.C., R.B.B., S.d.C.F. contributed reagents/materials/analysis tools; G.S., F.T.L., M.M. wrote the paper. All the authors critically reviewed the manuscript for important content and approved the final manuscript.

Conflicts of Interest: The authors declare no conflict of interest.

\section{References}

1. Fock, K.M. Review article: The epidemiology and prevention of gastric cancer. Aliment. Pharmacol. Ther. 2014, 40, 250-260. [CrossRef] [PubMed]

2. $\quad$ D'Ugo, D.; Persiani, R.; Zoccali, M.; Cananzi, F.; Vigorita, V.; Mazzeo, P.; Tufo, A.; Biondi, A. Surgical issues after neoadjuvant treatment for gastric cancer. Eur. Rev. Med. Pharmacol. Sci. 2010, 14, 315-319. [PubMed]

3. Zuo, Q.F.; Cao, L.Y.; Yu, T.; Gong, L.; Wang, L.N.; Zhao, Y.L.; Xiao, B.; Zou, Q.M. Microrna-22 inhibits tumor growth and metastasis in gastric cancer by directly targeting mmp14 and snail. Cell Death Dis. 2015, 6, e2000. [CrossRef] [PubMed]

4. Loffek, S.; Schilling, O.; Franzke, C.W. Series "matrix metalloproteinases in lung health and disease": Biological role of matrix metalloproteinases: A critical balance. Eur. Respir. J. 2011, 38, 191-208. [CrossRef] [PubMed]

5. Nagase, H.; Visse, R.; Murphy, G. Structure and function of matrix metalloproteinases and timps. Cardiovasc. Res. 2006, 69, 562-573. [CrossRef] [PubMed]

6. Liu, H.Y.; Gu, W.J.; Wang, C.Z.; Ji, X.J.; Mu, Y.M. Matrix metalloproteinase-9 and -2 and tissue inhibitor of matrix metalloproteinase-2 in invasive pituitary adenomas: A systematic review and meta-analysis of case-control trials. Medicine 2016, 95, e3904. [CrossRef] [PubMed]

7. Sariahmetoglu, M.; Crawford, B.D.; Leon, H.; Sawicka, J.; Li, L.; Ballermann, B.J.; Holmes, C.; Berthiaume, L.G.; Holt, A.; Sawicki, G.; et al. Regulation of matrix metalloproteinase-2 (mmp-2) activity by phosphorylation. FASEB J. 2007, 21, 2486-2495. [CrossRef] [PubMed]

8. Kargozaran, H.; Yuan, S.Y.; Breslin, J.W.; Watson, K.D.; Gaudreault, N.; Breen, A.; Wu, M.H. A role for endothelial-derived matrix metalloproteinase- 2 in breast cancer cell transmigration across the endothelial-basement membrane barrier. Clin. Exp. Metastasis 2007, 24, 495-502. [CrossRef] [PubMed] 
9. Taniwaki, K.; Fukamachi, H.; Komori, K.; Ohtake, Y.; Nonaka, T.; Sakamoto, T.; Shiomi, T.; Okada, Y.; Itoh, T.; Itohara, S.; et al. Stroma-derived matrix metalloproteinase (mmp)-2 promotes membrane type 1-mmp-dependent tumor growth in mice. Cancer Res. 2007, 67, 4311-4319. [CrossRef] [PubMed]

10. Monig, S.P.; Baldus, S.E.; Hennecken, J.K.; Spiecker, D.B.; Grass, G.; Schneider, P.M.; Thiele, J.; Dienes, H.P.; Holscher, A.H. Expression of $\mathrm{mmp}-2$ is associated with progression and lymph node metastasis of gastric carcinoma. Histopathology 2001, 39, 597-602. [CrossRef] [PubMed]

11. Noh, S.; Jung, J.J.; Jung, M.; Kim, T.S.; Park, C.H.; Lim, S.J.; Jeung, H.C.; Cheol, H.; Chung, H.C.; Rha, S.Y. Mmp-2 as a putative biomarker for carcinomatosis in gastric cancer. Hepatogastroenterology 2011, 58, 2015-2019. [CrossRef] [PubMed]

12. Kasi, P.D.; Tamilselvam, R.; Skalicka-Wozniak, K.; Nabavi, S.F.; Daglia, M.; Bishayee, A.; Pazoki-Toroudi, H.; Nabavi, S.M. Molecular targets of curcumin for cancer therapy: An updated review. Tumour Biol. 2016, 37, 13017-13028. [CrossRef] [PubMed]

13. Mitra, A.; Chakrabarti, J.; Banerji, A.; Chatterjee, A.; Das, B.R. Curcumin, a potential inhibitor of mmp-2 in human laryngeal squamous carcinoma cells hep2. J. Environ. Pathol. Toxicol. Oncol. 2006, 25, 679-690. [CrossRef] [PubMed]

14. Liu, W.L.; Chang, J.M.; Chong, I.W.; Hung, Y.L.; Chen, Y.H.; Huang, W.T.; Kuo, H.F.; Hsieh, C.C.; Liu, P.L. Curcumin inhibits lin-28a through the activation of miRNA-98 in the lung cancer cell line a549. Molecules 2017, 22. [CrossRef] [PubMed]

15. Lee, A.Y.; Fan, C.C.; Chen, Y.A.; Cheng, C.W.; Sung, Y.J.; Hsu, C.P.; Kao, T.Y. Curcumin inhibits invasiveness and epithelial-mesenchymal transition in oral squamous cell carcinoma through reducing matrix metalloproteinase 2, 9 and modulating p53-e-cadherin pathway. Integr. Cancer Ther. 2015, 14, 484-490. [CrossRef] [PubMed]

16. Kasinski, A.L.; Du, Y.; Thomas, S.L.; Zhao, J.; Sun, S.Y.; Khuri, F.R.; Wang, C.Y.; Shoji, M.;

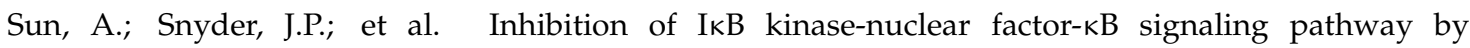
3,5-bis(2-flurobenzylidene)piperidin-4-one (EF24), a novel monoketone analog of curcumin. Mol. Pharmacol. 2008, 74, 654-661. [CrossRef] [PubMed]

17. Lima, F.T.; Seba, V.; Silva, G.; Torrezan, G.S.; Polaquini, C.R.; Pinholato, V.C.; Baek, S.J.; Fachin, A.L.; Regasini, L.O.; Marins, M. The curcumin analog ch-5 exerts anticancer effects in human osteosarcoma cells via modulation of transcription factors $\mathrm{p} 53 / \mathrm{sp} 1$. Manuscript in preparation.

18. Lima, F.T. Cytotoxic and Epigenetic Activity of Diphenylpentanoids Analogs of Curcumin in Human and Canine Osteosarcoma Cells; University of Ribeirão Preto: Ribeirão Preto, Brazil, 2017.

19. Chambers, A.F.; Groom, A.C.; MacDonald, I.C. Dissemination and growth of cancer cells in metastatic sites. Nat. Rev. Cancer 2002, 2, 563-572. [PubMed]

20. Hunter, K.W.; Crawford, N.P.S.; Alsarraj, J. Mechanisms of metastasis. Breast Cancer Res. 2008, 10 (Suppl. 1), S2. [CrossRef] [PubMed]

21. Niedzwiecki, A.; Roomi, M.W.; Kalinovsky, T.; Rath, M. Anticancer efficacy of polyphenols and their combinations. Nutrients 2016, 8. [CrossRef] [PubMed]

22. Banerji, A.; Chakrabarti, J.; Mitra, A.; Chatterjee, A. Effect of curcumin on gelatinase a (MMP-2) activity in B16F10 melanoma cells. Cancer Lett. 2004, 211, 235-242. [CrossRef] [PubMed]

23. Cao, A.; Li, Q.; Yin, P.; Dong, Y.; Shi, H.; Wang, L.; Ji, G.; Xie, J.; Wu, D. Curcumin induces apoptosis in human gastric carcinoma ags cells and colon carcinoma ht-29 cells through mitochondrial dysfunction and endoplasmic reticulum stress. Apoptosis 2013, 18, 1391-1402. [CrossRef] [PubMed]

24. Zhou, S.; Yao, D.; Guo, L.; Teng, L. Curcumin suppresses gastric cancer by inhibiting gastrin-mediated acid secretion. FEBS Open Bio 2017, 7, 1078-1084. [CrossRef] [PubMed]

25. Chen, Q.Y.; Zheng, Y.; Jiao, D.M.; Chen, F.Y.; Hu, H.Z.; Wu, Y.Q.; Song, J.; Yan, J.; Wu, L.J.; Lv, G.Y. Curcumin inhibits lung cancer cell migration and invasion through rac1-dependent signaling pathway. J. Nutr. Biochem. 2014, 25, 177-185. [CrossRef] [PubMed]

26. Guan, H.; Cai, J.; Zhang, N.; Wu, J.; Yuan, J.; Li, J.; Li, M. Sp1 is upregulated in human glioma, promotes mmp-2-mediated cell invasion and predicts poor clinical outcome. Int. J. Cancer 2012, 130, 593-601. [CrossRef] [PubMed]

27. Hung, W.C.; Tseng, W.L.; Shiea, J.; Chang, H.C. Skp2 overexpression increases the expression of mmp-2 and mmp-9 and invasion of lung cancer cells. Cancer Lett. 2010, 288, 156-161. [CrossRef] [PubMed] 
28. Yue, P.Y.; Leung, E.P.; Mak, N.K.; Wong, R.N. A simplified method for quantifying cell migration/wound healing in 96-well plates. J. Biomol. Screen. 2010, 15, 427-433. [CrossRef] [PubMed]

29. Zheng, X.H.; Nie, X.; Liu, H.Y.; Fang, Y.M.; Zhao, Y.; Xia, L.X. TMPyP4 promotes cancer cell migration at low doses, but induces cell death at high doses. Sci. Rep. 2016, 6. [CrossRef] [PubMed]

(C) 2018 by the authors. Licensee MDPI, Basel, Switzerland. This article is an open access article distributed under the terms and conditions of the Creative Commons Attribution (CC BY) license (http://creativecommons.org/licenses/by/4.0/). 